\title{
CARBOXYLIC ACIDS IN THE FLOWERS OF VERONICA SPICATA L. AND VERONICA INCANA L.
}

\author{
Alla Kovaleva, Ain Raal, Tetiana Ilina, Alina Osmachko, Olga Goryacha, \\ Ludmila Omelyanchik, Oleh Koshovyi
}

In the Ukrainian flora, species of Veronica L. genus (Plantaginaceae Juss.) are classified into 8 sections. Among the representatives of Pseudolysimachion W. D. J. Koch section in the Kharkiv region, Veronica spicata L. (spike speedwell) and Veronica incana L. (Veronica spicata L. subsp. incana (L.) Walters, silver speedwell) are common. Plants are used for the treatment of upper respiratory tract diseases, malignant neoplasms, gastrointestinal tract and genitourinary system disorders, diabetes mellitus.

The aim of the research was to study the carboxylic acids of flowers of Veronica spicata L. and Veronica incana L. Materials and methods. The objects of the research were flowers of Veronica spicata L. and Veronica incana L., collected in the flowering stage in the Botanical Garden of Karazin University (Kharkiv, Ukraine) in summer 2018. The study of carboxylic acid composition was performed by chromatography-mass spectrometry on a 6890N MSD/DS Agilent Technologies chromatograph with a 5973N mass spectrometric detector. Identification of methyl esters of acids was performed using data from the mass spectrum libraries NIST 05 and Willey 2007 in a combination with programs for the identification of AMDIS and NIST; also, their retention time and the retention times of standard compounds were compared.

Results. In Veronica incana L. flowers, 37 carboxylic acids were identified and quantified, constituting $1.05 \%$. In Veronica spicata L. flowers, 32 carboxylic acids were identified and quantified, the total content of which was $2.75 \%$.

Conclusions. A higher carboxylic acid content was established in the flowers of Veronica spicata L. The fatty acid composition of Veronica incana L. flowers is characterized by a comparable content of saturated and unsaturated acids, while in Veronica spicata L. flowers, unsaturated fatty acids prevail over saturated fatty acids. The content of aromatic acids in the flowers of studied species was comparable. The characteristic carboxylic acids in the flowers of Veronica incana L. are oxalic, 3-hydroxy-2-methylglutaric, pentadecanoic, heneicosanoic, tricosanic,4-hydroxybenzoic, 4-methoxybenzoic and 3,4dimethoxybenzoic acids; in the flowers of Veronica spicata L. -2-hydroxy-3-methylglutaric, $\alpha$-furanic and homovanillic acids Keywords: carboxylic acids, GC-MS analysis, Veronica spicata L., Veronica incana L.

How to cite:

Kovaleva, A., Raal, A., Ilina, T., Osmachko, A., Goryacha, O., Omelyanchik, L., Koshovyi, O. (2022). Carboxylic acids in the flowers of Veronica spicata 1. and Veronica incana L.. ScienceRise: Pharmaceutical Science, 1 (35), 37-43. doi: http://doi.org/10.15587/1729-4061.2022.253541

(C) The Author(s) 2022

This is an open access article under the Creative Commons CC BY license hydrate

\section{Introduction}

The genus Veronica L. (Plantaginaceae Juss.) [1] is represented by approximately 70 species in the Ukrainian flora [2]; according to other sources, the corresponding figure is 48 species classified into 8 sections [3, 4]. Among the species of Pseudolysimachion W. D. J. Koch section in the Kharkiv region, Veronica spicata L. (spike speedwell) and Veronica incana L. (by the International Plant Name Index Veronica spicata L. subsp. incana (L.) Walters, silver speedwell) are common [5].

The chemical profiles of most wild Veronica species of the Ukrainian flora are poorly characterized. It is known that the species of Pseudolysimachion W. D. J. Koch section accumulate cornoside, glycosides and derivatives of 6hydroxyflavone acylated by phenolic acids [6,7]; iridoids [8, 9]. In species of Pseudolysimachion W. D. J. Koch section, iridoid glucosides were reported $[10,11]$. The major compounds in the essential oil extracted from the aerial parts of Veronica spicata were monoterpenoids and sesquiterpenoids. Phenolic compounds are represented by aromatic acids and flavonoids [12, 13]. In $V$. incana herb, flavonoids were reported $[14,15]$.

The species of Pseudolysimachion W. D. J. Koch section have been important in ethnomedicine as remedies for the treatment of upper respiratory tract diseases and malignant neoplasms; as well as gastrointestinal tract and genitourinary system disorders, diabetes mellitus, various dermatological diseases; they show analgesic, sedative, hemostatic and wound healing effects $[6,16]$. Veronica spicata is used as an expectorant [17]. In experimental studies, antitumor $[6,11]$ antioxidant and antimicrobial $[12,18]$ and anti-inflammatory [19] activities of Veronica spp. were shown [20, 21].

Fatty acids [22, 23] and phenolic acids [24] are considered as potential chemotaxonomic markers [25]. Previously, we have established the carboxylic acid composition of the flowers and leaves of V. longifolia L., another representative of Pseudolysimachion W. D. J. Koch section [26]. As a continuation of our research into chemical composition of Pseudolysimachion W. D. J. Koch section species, the aim of the present research was 
to study the composition of carboxylic acids of the flowers of Veronica spicata L. and Veronica incana L. in order to establish characteristic carboxylic acids.
2. Planning (methodology) of the research

In Fig. 1 a graphical representation of the research planning process is shown.

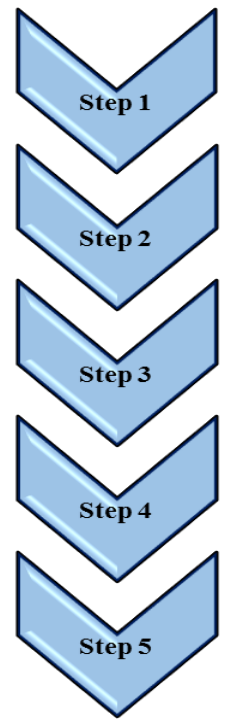

3. Materials and Methods Plant material

The flowers of Veronica spicata L. and Veronica incana L. (about 50 grams of each) were collected in the flowering stage in the Botanical Garden of Karazin University (Kharkiv, Ukraine) in summer 2018 (North latitude $50^{\circ} 01^{\prime} 46^{\prime \prime}$; East longitude $\left.36^{\circ} 14^{\prime} 02^{\prime \prime}\right)$. Voucher specimens Nos. 26/06/2018 and 29/06/2018 are deposited at the Pharmacognosy Department (National University of Pharmacy, Kharkiv, Ukraine). The identity of Veronica L. species was established with the consulting assistance of Yurij G. Gamulya, PhD in Biology (Ecology), Associate Professor, Herbarium Curator of V. N. Karazin Kharkiv National University, and Tetiana M. Gontova, D.Sc. (Pharmacy), Professor of Pharmacognosy Department of the National University of Pharmacy [27]. Herbal materials were dried in the shade and at room temperature $\left(25^{\circ} \mathrm{C}\right)$ for 3 days and stored in paper bags protected from light.

Isolation of carboxylic acids

To $50 \mathrm{mg}$ of the air-dried raw materials in a $2 \mathrm{ml}$ vial, an internal standard (50 $\mathrm{mg}$ of tridecane in hexane) was added, as well as $1.0 \mathrm{~mL}$ of a methylation agent $\left(\mathrm{BCl}_{3}\right.$ in methanol, $14 \%$ solution, Supelco 3-3033) [26]. The mixture was heated in a sealed vial for $8 \mathrm{~h}$ at $65{ }^{\circ} \mathrm{C}$ in order to perform the extraction and hydrolysis of fats and other esters as well as simultaneous methylation of fatty acids and other organic acids. The reaction mixture was decanted, and the precipitate was diluted in $1 \mathrm{~mL}$ of distilled water; methyl esters of carboxylic acids were extracted with $0.2 \mathrm{~mL}$ methylene chloride. The mixture was gently shaken several times within an hour and then the obtained extract of the methyl esters was chromatographed [28, 29].

Identification and comparative content determination of carboxylic acids

The gas chromatography-mass spectrometry (GCMS) analysis of carboxylic acids was performed on Ag- ilent Technologies 5973N/6890N MSD/DS GC-MS (USA) according to the previously described procedure $[28,30]$. The system was equipped with INNOWAX capillary column $(30 \mathrm{~m} \times 0.25 \mathrm{~mm}$, i.d. of $0.25 \mu \mathrm{m})$. The column oven temperature was gradually increased from $50^{\circ} \mathrm{C}$ to $250^{\circ} \mathrm{C}$ at $4^{\circ} \mathrm{C} / \mathrm{min}$. Helium was used as the carrier gas at $1.2 \mathrm{~mL} / \mathrm{min}$, and the sample $(2 \mu \mathrm{L})$ was injected in the splitless ratio; the injector temperature was $250{ }^{\circ} \mathrm{C}$. The MS conditions were as follows: the ionization voltage $70 \mathrm{eV}$; the acquisitions scan mass range of 40$500 \mathrm{amu}$; the ion source temperature $230{ }^{\circ} \mathrm{C}$ at a sampling rate of $1.0 \mathrm{scan} / \mathrm{s}$. Identification of methyl esters of acids was performed based on the calculation of the equivalent length of the aliphatic chain (ECL) by using data from the mass spectra libraries NIST 05 and Willey 2007 in combination with programs for identifying AMDIS and NIST; the retention time of esters was also compared with the retention time of standard compounds (Sigma) [31, 32].

\section{Statistical analysis}

Statistical processing of the results was performed using the Student's t-test. Statistical properties of random variables with n-dimensional normal distribution are given by their correlation matrices, which can be calculated from the original matrices. The reliability of the compared values was estimated using the Student, Wilcoxon, Mann-Whitney criteria with the probability level of $\leq 0.05$ on a computer using Statistica 6.0 and Word Excel programs $[33,34]$. The results were expressed as mean \pm standard deviation (SD).

\section{Research results.}

As the result of the present study, 37 carboxylic acids were identified and quantified in $V$. incana $\mathrm{L}$. flow

ers, and 32 carboxylic acids were identified and quantified in V. spicata L. flowers (Fig. 2, 3, Table 1). 
Table 1

Comparative content of Carboxylic Acids in Veronica incana L. and Veronica spicata L. flowers

\begin{tabular}{|c|c|c|c|c|}
\hline \multirow{3}{*}{ No } & \multirow{3}{*}{ Carboxylic acid } & \multirow{3}{*}{ RI } & \multicolumn{2}{|c|}{ Veronica species } \\
\hline & & & V. incana & V. spicata \\
\hline & & & \multicolumn{2}{|c|}{ Content, $\mathrm{mg} / \mathrm{kg}^{*}$} \\
\hline 1 & $\begin{array}{l}\text { 3-Hydroxy-2-methylglutaric acid } \\
\text { methylpentanedioic) }\end{array}$ & 1064 & $137.24 \pm 3.57$ & - \\
\hline 2 & $\alpha$-Furanoic (furan-2-carboxylic, pyromucic) & 1086 & - & $36.22 \pm 0.98$ \\
\hline 3 & Caproic (hexanoic) & 1120 & $5.63 \pm 0.14$ & $5.65 \pm 0.16$ \\
\hline 4 & Veratric (3,4-dimethoxybenzoic) & 1172 & $265.56 \pm 7.97$ & - \\
\hline 5 & Oxalic (ethanedioic) & 1359 & $85.57 \pm 2.24$ & - \\
\hline 6 & p-Hydroxybenzoic (4-hydroxybenzoic) & 1451 & $486.57 \pm 14.35$ & - \\
\hline 7 & Malonic (propanedioic) & 1477 & $265.73 \pm 7.86$ & $920.54 \pm 27.61$ \\
\hline 8 & Levulinic (4-oxopentanoic) & 1501 & $449.85 \pm 13.18$ & $7700.14 \pm 244.86$ \\
\hline 9 & Fumaric (trans-butenedioic) & 1516 & $25.69 \pm 0.69$ & $21.56 \pm 0.58$ \\
\hline 10 & Succinic (butanedioic) & 1575 & $345.10 \pm 10.35$ & $594.19 \pm 17.82$ \\
\hline 11 & Benzoic (benzoic) & 1600 & $566.22 \pm 17.27$ & $498.46 \pm 15.05$ \\
\hline 12 & Homovanillic (2-(4-hydroxy-3-methoxyphenyl)acetic) & 1657 & - & $22.79 \pm 0.62$ \\
\hline 13 & Phenylacetic ( $\alpha$-toluic) & 1746 & $14.59 \pm 0.37$ & $7.99 \pm 0.20$ \\
\hline 14 & Salicylic (2-hydroxybenzoic) & 1757 & $20.05 \pm 0.50$ & $3.7 \pm 0.09$ \\
\hline 15 & Lauric (dodecanoic) & 1793 & $19.68 \pm 0.48$ & $11.11 \pm 0.27$ \\
\hline 16 & 3-Hydroxy-2-methylglutaric (3-hydroxy-2- methylpentanedioic) & 1917 & - & $16.12 \pm 0.40$ \\
\hline 17 & Myristic (tetradecanoic) & 1994 & $121.02 \pm 3.63$ & $46.39 \pm 1.25$ \\
\hline 18 & Malic (2-hydroxybutanedioic) & 2008 & $536.27 \pm 16.08$ & $2879.71 \pm 89.36$ \\
\hline 19 & Pentadecanoic (pentadecilic) & 2101 & $29.69 \pm 0.74$ & - \\
\hline 20 & Azelaic (nonanedioic) & 2114 & $68.15 \pm 1.92$ & $141.05 \pm 3.92$ \\
\hline 21 & Palmitic (hexadecanoic) & 2204 & $1137.67 \pm 35.95$ & $2682.47 \pm 73.49$ \\
\hline 22 & Palmitoleic (cis-9-hexadecanoic) & 2223 & $69.82 \pm 2.04$ & $109.52 \pm 3.29$ \\
\hline 23 & Margarinic (heptadecanoic) & 2292 & $34.54 \pm 0.96$ & $57.42 \pm 1.60$ \\
\hline 24 & Citric (2-hydroxy-1,2,3-propanetricarboxylic) & 2367 & $592.59 \pm 17.36$ & $4747.51 \pm 145.27$ \\
\hline 25 & Stearic (octadecanoic) & 2384 & $279.15 \pm 7.82$ & $157.43 \pm 4.57$ \\
\hline 26 & Oleic (cis-9-octadecenoic) & 2402 & $372.64 \pm 10.43$ & $390.22 \pm 11.36$ \\
\hline 27 & Linoleic (9,12-octadecadienoic) & 2443 & $1163.90 \pm 36.31$ & $2304.41 \pm 71.67$ \\
\hline 28 & Linolenic (cis,cis,cis-6,9,12-octadecatrienoic) & 2490 & $901.67 \pm 28.87$ & $1452.55 \pm 43.43$ \\
\hline 29 & Vanillic (4-hydroxy-3-methoxybenzoic) & 2522 & $649.78 \pm 18.45$ & $1868.65 \pm 55.69$ \\
\hline 30 & 2-Hydroxypalmitic (2-hydroxyhexadecanoic) & 2542 & $133.24 \pm 3.67$ & $63.32 \pm 1.77$ \\
\hline 31 & Arachidic (eicosanoic) & 2543 & $121.05 \pm 3.53$ & $78.19 \pm 2.17$ \\
\hline 32 & Heneicosanoic & 2597 & $15.59 \pm 0.42$ & - \\
\hline 33 & Begenic (docosanoic) & 2698 & $249.78 \pm 7.27$ & $175.36 \pm 5.20$ \\
\hline 34 & Tricosanoic & 2743 & $28.31 \pm 0.76$ & - \\
\hline 35 & p-Methoxybenzoic (4-methoxybenzoic) & 2780 & $94.86 \pm 2.68$ & - \\
\hline 36 & Syringic (4-hydroxy-3,5-dimethoxybenzoic) & 2793 & $103.63 \pm 2.90$ & $13.24 \pm 0.36$ \\
\hline 37 & p-Coumaric (3-(4-hydroxyphenyl)-propenoic) & 2801 & $195.11 \pm 5.85$ & $11.24 \pm 0.30$ \\
\hline 38 & Gentisic (2,5-dihydroxybenzoic) & 2805 & $57.25 \pm 1.57$ & $25.21 \pm 0.69$ \\
\hline 39 & Lignoceric (tetracosanoic) & 2843 & $380.36 \pm 11.30$ & $208.65 \pm 6.18$ \\
\hline 40 & Ferulic (3-methoxy-4-hydroxycinnamic) & 2919 & $441.13 \pm 13.23$ & $274.11 \pm 7.98$ \\
\hline \multicolumn{3}{|c|}{ Total } & $10464.68 \pm 339.05$ & $27525.12 \pm 872.55$ \\
\hline
\end{tabular}

Note: $* m g / k g$ in the air-dried herbal materials, «-» the compound was not identified 


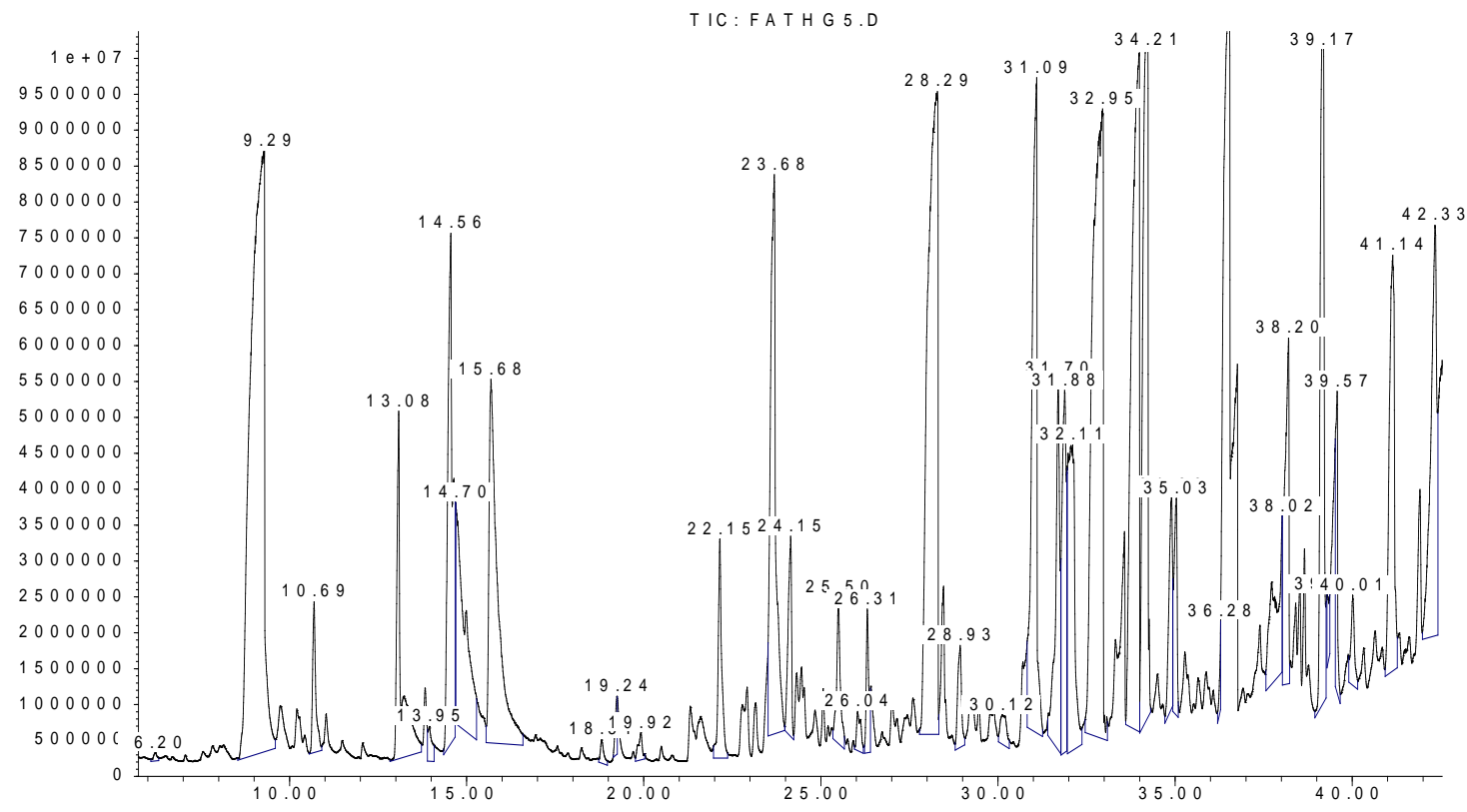

Fig. 2. The typical GC-MS chromatogram of methyl esters of carboxylic acids of Veronica incana L. flowers

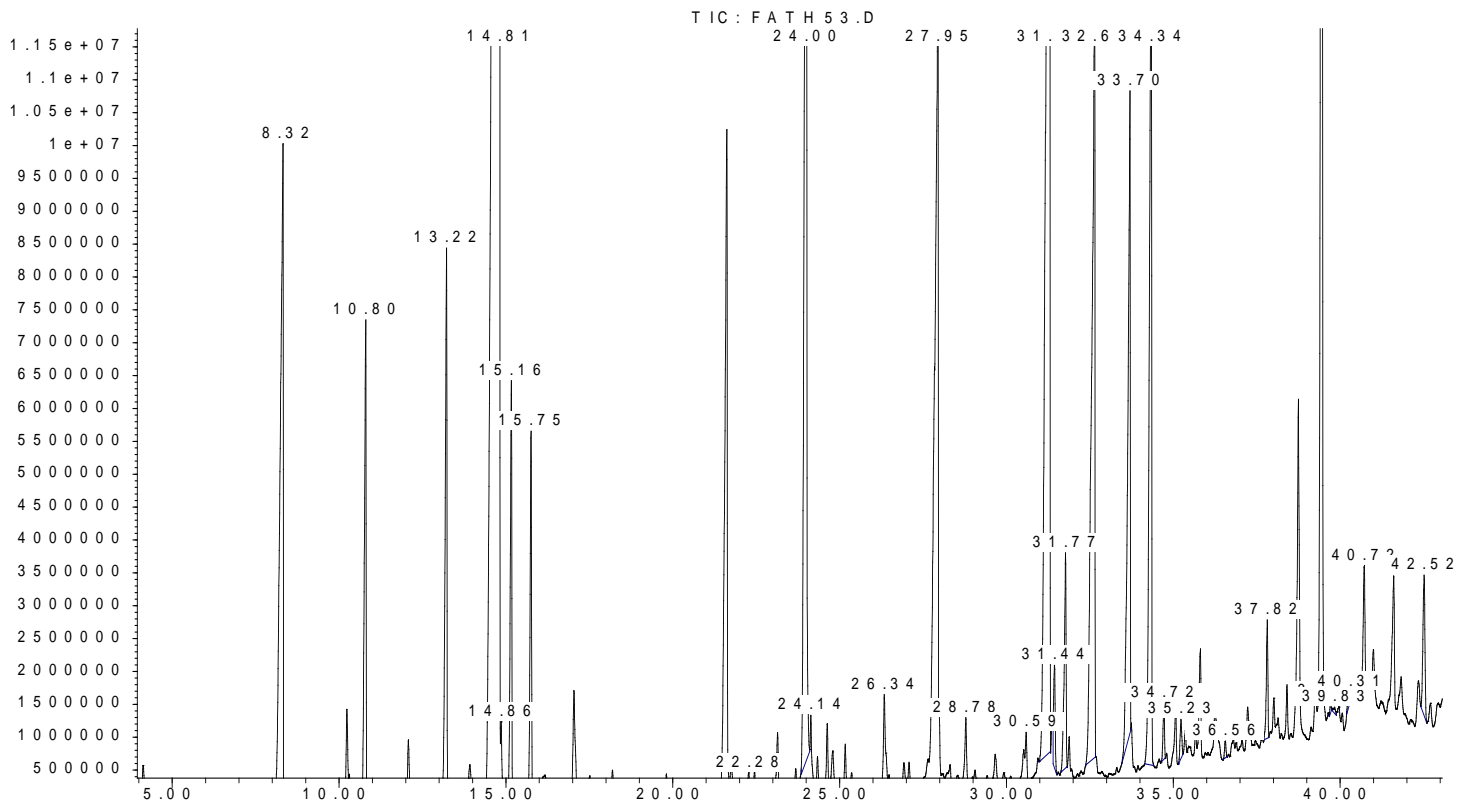

Fig. 3. The typical GC-MS chromatogram of methyl esters of carboxylic acids ofVeronica spicata L. flowers

\section{Discussion}

Only a few studies have been found on the chemical composition of $V$. spicata and $V$. incana. Naimushina and Zykova [20] reported the presence of 40 components in $V$. spicata essential oil, which were mainly oxygenated terpenoids and hydrocarbons. According to [12], the main compounds of the essential oil of $V$. spicata were phytol, heptacosane and pentacosane. Also, 10 phenolic compounds (chrysin, rutin, quercitrin and cichoric, ferulic, protocatehuic, rosmarinic, syringic and tannic acids) were identified and quantified in V. spicata. Previously, five 6-hydroxyluteolin glycosides acylated with phenolic acids, called spicosides B-F were detected in V. spicata, and the survey of other species of Veronica has shown that this type of flavonoid is common in species belong- ing to the subgenus Pseudolysimachium, which may be a possible chemosystematic marker [25].

In the herb of $V$. incana growing in Yakutia, tannins, flavonoids, coumarins and iridoids were identified, and the content of total phenolics, tannins and flavonoids was established [21].

In $V$. incana flowers, the total carboxylic acid content was $10464.68 \mathrm{mg} / \mathrm{kg}$. In the total content of carboxylic acids, low-molecular aliphatic acids account for $23.95 \%(2506.19 \mathrm{mg} / \mathrm{kg})$, fatty acids make up $48.39 \%$ $(5063.74 \mathrm{mg} / \mathrm{kg})$, and aromatic acids constitute $27.66 \%$ ( $2894.75 \mathrm{mg} / \mathrm{kg}$ ). The fatty acid composition of $V$. inca$n a$ flowers is characterized by the comparable content of saturated and unsaturated acids (2555.71 and $2508.03 \mathrm{mg} / \mathrm{kg}$, respectively). Benzoic acid and its deriv- 
atives are the dominant aromatic acids $(1413.21 \mathrm{mg} / \mathrm{kg}$ or $13.50 \%$ of the total content); the content of phenyl and phenolic acids is significantly lower $(845.3 \mathrm{mg} / \mathrm{kg}$ or $8.08 \%$ of the total content); hydroxycinnamic acids are a minor group of carboxylic acids $(636.24 \mathrm{mg} / \mathrm{kg}$ or $6.08 \%$ of the total carboxylic acid content).

In $V$. incana flowers, the dominant low-molecular aliphatic acids are citric acid and malic acid (592.59 and $536.27 \mathrm{mg} / \mathrm{kg}$, respectively); linoleic acid and palmitic acid are the major fatty acids (1163.90 and $1137.67 \mathrm{mg} / \mathrm{kg}$, respectively); among aromatic acids, vanillic acid and benzoic acid prevail (649.78 and $566.22 \mathrm{mg} / \mathrm{kg}$, respectively).

The total content of the carboxylic acids in $\mathrm{V}$. spicata flowers is $27525.12 \mathrm{mg} / \mathrm{kg}$, of which the lowmolecular aliphatic acids constitute $61.96 \%$ (17057.04 $\mathrm{mg} / \mathrm{kg}$ ), the fatty acids account for $28.14 \%$ (7742.69 $\mathrm{mg} / \mathrm{kg}$ ), and the aromatic acids make up $9.90 \%$ of the total carboxylic acid content $(2725.39 \mathrm{mg} / \mathrm{kg})$. Unsaturated fatty acids $(4256.70 \mathrm{mg} / \mathrm{kg}$ ) were detected to prevail in the total amount of the fatty acids, while saturated fatty acids constituted $3485.99 \mathrm{mg} / \mathrm{kg}$. In the total amount of aromatic acids, phenyl- and phenolcarboxylic acids were dominant (1941.58 mg/kg or $7.05 \%$ of the total carboxylic acid content); a significantly lower content of benzoic acid was established (498.46 mg/kg or $1.81 \%$ of the total content); hydroxycinnamic acids were the minor group (285.25 $\mathrm{mg} / \mathrm{kg}$ or $1.04 \%$ ). The following carboxylic acids are dominant in $V$. spicata flowers: levulinic acid (the content of which reaches up to $7700.14 \mathrm{mg} / \mathrm{kg}$ ) prevails in the total amount of the low-molecular-weight aliphatic acids; palmitic and linoleic acids (2682.47 and $2304.41 \mathrm{mg} / \mathrm{kg}$, respectively) are the dominant higher fatty acids; vanillic acid is the major aromatic acid $(1868.65 \mathrm{mg} / \mathrm{kg})$.

It is noteworthy that percentages of benzoic acid and its derivatives $(13.50 \%)$, and hydroxycinnamic acids (6.08 $\%$ ) in the total carboxylic acid content in $V$. incana flowers are significantly higher than those in $V$. spicata flowers (1.81\% and $1.04 \%$, respectively). Whereas the percentage of phenyl- and phenolcarboxylic acids in the total carboxylic acid content in the flowers of $V$. incana and $V$. spicata is comparable ( $8.08 \%$ and $7.05 \%$, respectively).

Considering our previously reported data on the chemical composition of the flowers of $V$. longifolia [26], some features of aromatic acids profile of flowers of Pseudolysimachion W. D. J. Koch section Veronica species of Ukrainian flora are seen. The common acids are benzoic, vanillic and ferulic acids. Phenylacetic, salicylic, syringic, $p$-coumaric and gentisic acids are characteristic only for flowers of $V$. spicata and $V$. incana.

Also, based on data obtained, we could state that the highest content of carboxylic acids among the three studied species of the section Pseudolysimachion W. D. $\mathrm{J}$. Koch is observed in V. spicata flowers, with the highest content of low-molecular-weight aliphatic acids -
$1.70 \%$. The highest content of fatty acids was detected in the flowers of $V$. longifolia $-1.50 \%$. The content of aromatic acids in the flowers of $V$. incana and $V$. spicata is comparable $(0.29 \%$ and $0.27 \%$, respectively), and these values are almost 3 -folds higher than the content of aromatic acids in $V$. longifolia flowers $(0.10 \%)$.

The qualitative composition of carboxylic acids in $V$. incana is similar to that of $V$. longifolia flowers. Unlike $V$. spicata, both species produce oxalic, 3-hydroxy-2methylglutaric, heneicosanoic, tricosanic, 4-hydroxybenzoic acids, whereas the flowers of $V$. spicata differ in the presence of 2-hydroxy-3-methylglutaric, $\alpha$-furanic and homovanillic acids.

Raw materials containing aromatic acids are considered as a potential source of drugs for the treatment of metabolic syndrome, diabetes and heart disease $[35,36]$ and correction of immunity [37, 38]. Hypolipidemic and antidiabetic activity of ferulic acid was reported [39].

Study limitations. During the GC-MS study, several compounds were not identified due to the absence of their characteristics in NIST 05 and Willey 2007 mass spectra libraries, as well as in AMDIS and NIST programs.

The prospects for the further research. In future, it is reasonable to study a dependence of carboxylic acids composition on plant development, season, and growth conditions. Also, since studied herbal materials contain phytochemicals with hypolipidemic and antidiabetic activities, it is reasonable to obtain corresponding substances and study their hypoglycemic and hypolipidemic potential.

\section{Conclusions}

By means of GC-MS analysis, carboxylic acids were first studied in the flowers of Veronica spicata L. and Veronica incana $\mathrm{L}$. The content of carboxylic acids in the flowers of Veronica spicata is two times higher than in Veronica incana flowers. The characteristic carboxylic acids in Veronica spicata flowers are 2-hydroxy-3-methylglutaric, $\alpha$-furanic and homovanillic acids. Veronica incana flowers are notable for the presence of oxalic, 3-hydroxy-2methylglutaric, pentadecanoic, heneicosanoic, tricosanic, 4hydroxybenzoic, 4-methoxybenzoic and 3,4-dimethoxybenzoic acids. The data obtained can be employed as chemical tools for species identification.

\section{Conflicts of interest}

The authors declare that they have no conflicts of interest.

\section{Funding}

This work was supported by the Ministry of Health of Ukraine from the State Budget in the framework [grant number 2301020] "Scientific and scientifictechnical activity in the field of health protection" on the topic "Modern approaches to the creation of new medicines for a correction of metabolic syndrome".

\section{References}

1. Elenevskiy, A. G. (1978). Sistematika i geografiya veronik SSSR i prilezhaschih stran. Moscow: Nauka, 259.

2. Mosyakin, S. L., Fedoronchuk, M. M. (1999). Sosudistyie rasteniya Ukrainyi: Nomenklaturnyiy perechen. Kyiv: M. G. Institut botaniki im. Holodnogo, 345.

3. Elenevskiy, A. G. (1968). Zametki o veronikah sektsii Pseudolysimachia C. Koch. Biologicheskie nauki, 11, 65-69.

4. Elenevskiy, A. G. (1971). K sistematike Veronica spicata L. s. 1. Novosti Sistematiki Vysshyh Rasteniy, 8, $215-227$.

5. Kotov, M. I. (1960). Flora URSR. Kyiv: Vydavnytstvo akademiyi nauk URSR, 612. 
6. Salehi, B., Shivaprasad Shetty, M., V. Anil Kumar, N., Živković, J., Calina, D., Oana Docea, A. et. al. (2019). Veronica Plants - Drifting from Farm to Traditional Healing, Food Application, and Phytopharmacology. Molecules, 24 (13), 2454. doi: http://doi.org/10.3390/molecules24132454

7. Albach, D. C., Jensen, S. R., Özgökce, F., Grayer, R. J. (2005). Veronica: Chemical characters for the support of phylogenetic relationships based on nuclear ribosomal and plastid DNA sequence data. Biochemical Systematics and Ecology, 33 (11), $1087-1106$. doi: http://doi.org/10.1016/j.bse.2005.06.002

8. Jensen, S. R., Albach, D. C., Ohno, T., Grayer, R. J. (2005). Veronica: Iridoids and cornoside as chemosystematic markers. Biochemical Systematics and Ecology, 33 (10), 1031-1047. doi: http://doi.org/10.1016/j.bse.2005.03.001

9. Taskova, R., Peev, D., Handjieva, N. (2002). Iridoid glucosides of the genus Veronica s.l. and their systematic significance. Plant Systematics and Evolution, 231 (1-4), 1-17. doi: http://doi.org/10.1007/s006060200008

10. Taskova, R. M., Albach, D. C., Grayer, R. J. (2004). Phylogeny ofVeronica- a Combination of Molecular and Chemical Evidence. Plant Biology, 6 (6), 673-682. doi: http://doi.org/10.1055/s-2004-830330

11. Witkowska-Banaszczak, E., Durkiewicz, M., Bylka, W. (2017). Rodzaj Veronica L. - działanie, zastosowanie, stan badań. Postępy Fitoterapii, 18, 71-77.

12. Dunkić, V., Kosalec, I., Kosir, I., Potocnik, T., Cerenak, A., Koncic, M. et. al. (2015). Antioxidant and antimicrobial properties of Veronica spicata L. (Plantaginaceae). Current Drug Targets, 16 (14), 1660-1670. doi: http://doi.org/10.2174/1389450116666150531161820

13. Broda, B., Jaroniewski, W., Swiatek, L. (1960). O występowaniu kwasu kawowego w niektórych roślinach leczniczych. Acta Poloniae Pharmaceutica, 17, 301-306.

14. Danilova, N. S., Poskachina, E. R., Voronov, I. V., Semenova, V. V. (2016). Soderzhanie lyuteolin-7-glyukozida v nadzemnoy chasti Veronica incana (Scrophulariaceae) v Tsentralnoy Yakutii. Rastitelnye Resursy, 52, 405-413.

15. Gusev, N. F., Nemereshina, O. N. (2005). K issledovaniyu flavonoidov Veronica incana L. stepnogo Preduralya. Vestnik OGU, 12, 96-99.

16. Voronov, I. V., Poskachina, E. R., Danilova, N. S., Semenova, V. V. (2016). Resursnyiy potentsial po lyuteolin-7glyukozidu Veronica incana (scrophulariaceae) v Tsentralnoy Yakutii. Nauchnyiy zhurnal KubGAU, 120, 1364-1377.

17. Popović, Z., Smiljanić, M., Kostić, M., Nikić, P., Janković, S. (2014). Wild flora and its usage in traditional phytotherapy (Deliblato Sands, Serbia, South East Europe). Indian Journal of Traditional Knowledge, 13, 9-35.

18. Gusev, N. F., Nemereshina, O. N. (2005). Antibakterialnoe issledovanie preparatov iz vidov Veronica L. Preduralya. Ekogolizatsiya prirodopolzovaniya v APK. Selskohozyaystvennyie nauki, 4, 43-47.

19. Harput, U. S., Saracoglu, I., Inoue, M., Ogihara, Y. (2002). Anti-inflammatory and Cytotoxic Activities of Five Veronica Species. Biological and Pharmaceutical Bulletin, 25 (4), 483-486. doi: http://doi.org/10.1248/bpb.25.483

20. Naimushina, L. V., Zykova, I. D. (2015). Issledovanie osnovnyih klassov biologicheski aktivnyih veschestv veroniki koloskovoy (Veronica spicata L.), proizrastayuschey v nizhnem Priangare. Bulletin of KrasGAU, 6, 123-129.

21. Chemposov, V. V., Uvarov, D. M., Chirikova, N. K. (2021). Veronika sedaya (Veronica incana L.): himicheskiy sostav i primenenie. Estestvennye i Tekhnicheskie Nauki, 5 (156), 148-153.

22. Arslan, Y., Hacioğlu, B. T. (2018). Seed fatty acid compositions and chemotaxonomy of wild safflower (Carthamus L., Asteraceae) species in Turkey. Turkish Journal of Agriculture and Forestry, 42, 45-54. doi: http://doi.org/10.3906/tar-1708-68

23. Mongrand, S., Badoc, A., Patouille, B., Lacomblez, C., Chavent, M., Bessoule, J.-J. (2005). Chemotaxonomy of the Rubiaceae family based on leaf fatty acid composition. Phytochemistry, 66 (5), 549-559. doi: http://doi.org/10.1016/j.phytochem.2004.12.021

24. Lemma, B., Grehl, C., Zech, M., Mekonnen, B., Zech, W., Nemomissa, S. et al. (2019). Phenolic Compounds as Unambiguous Chemical Markers for the Identification of Keystone Plant Species in the Bale Mountains, Ethiopia. Plants, 8 (7), 228. doi: http://doi.org/10.3390/plants8070228

25. Albach, D. C., Grayer, R. J., Kite, G. C., Jensen, S. R. (2005). Veronica: Acylated flavone glycosides as chemosystematic markers. Biochemical Systematics and Ecology, 33 (11), 1167-1177. doi: http://doi.org/10.1016/j.bse.2005.01.010

26. Osmachko, A., Kovalyova, A., Koshovyy, O., Goryachaya, O. (2013). Gas Chromatographic-Mass Spectrometric Studies of Organic Acids of Veronica longifolia L. The Pharma Innovation Journal, 2, 42-46.

27. Kotov, M. I., Prokudin, Yu. N., Barbarich, A. I. et. al. (1999). Opredelitel Vyisshih Rasteniy Ukrainyi. Kyiv: Fitosotsiotsentr, 548.

28. Ilina, T. V., Goryacha, O. V., Kovalyova, A. M., Koshovyi, O. M. (2017). Carboxylic acids and amino acids of Galium pseudomollugo herb. Der Pharma Chemica, 9 (11), 91-94.

29. Koshovyi, O., Raal, A., Kireyev, I., Tryshchuk, N., Ilina, T., Romanenko, Y. et. al. (2021). Phytochemical and Psychotropic Research of Motherwort (Leonurus cardiaca L.) Modified Dry Extracts. Plants, 10 (2), 230. doi: http://doi.org/10.3390/plants10020230

30. Krivoruchko, E., Markin, A., Samoilova, V.A., Ilina, T., Koshovyi, O. (2018). Research in the chemical composition of the bark of sorbus aucuparia. Ceska a Slovenska Farmacie, 67 (3), 113-115.

31. Kovalyova, A. M., Ilina, T. V., Osmachko, A. P., Koshovyi, O. M., Grudko, I. V. (2020). Carboxylic Acids from Herbs of Veronica austriaca, V. cuneifolia, and V. armena. Chemistry of Natural Compounds, 56 (6), 1111-1113. doi: http://doi.org/10.1007/s10600020-03238-1

32. Krivoruchko, E., Kanaan, H., Samoilova, V., Ilyina, T., Koshovyi, O. (2017). Carboxylic acids from brown algae Fucus vesiculosus and Padina pavonica. Ceska a Slovenska Farmacie, 66, 287-289.

33. Derzhavna Farmakopeia Ukrainy. Vol. 3 (2018). Kharkiv: Derzhavne pidpryiemstvo «Ukrainskyi naukovyi farmakopeinyi tsentr yakosti likarskykh zasobiv», 416.

34. Bondarenko, V. H., Kanivska, I. Y., Paramonova, S. M. (2006). Teoriia ymovirnostei i matematychna statystyka. Kyiv: NTUU "KPI", 125.

35. Zagayko, A. L., Kolisnyk, T. Y., Chumak, O. I., Ruban, O. A., Koshovyi, O. M. (2018). Evaluation of anti-obesity and lipid-lowering properties of Vaccinium myrtillus leaves powder extract in a hamster model. Journal of Basic and Clinical Physiology and Pharmacology, 29 (6), 697-703. doi: https://doi.org/10.1515/jbcpp-2017-0161

36. Pankaj, G. J, Sanjay, J. S. (2016). Isolation, characterization and hypolipidemic activity of ferulic acid in high-fat-dietinduced hyperlipidemia in laboratory rats. EXCLI Journal, 15, 599-613. doi: http://doi.org/10.17179/excli2016-394

37. Ilina, T., Skowrońska, W., Kashpur, N., Granica, S., Bazylko, A., Kovalyova, A., Koshovyi, O. (2020). Immunomodulatory Activity and Phytochemical Profile of Infusions from Cleavers Herb. Molecules, 25 (16), 3721. doi: https://doi.org/10.3390/ molecules 25163721 
38. Choi, R., Kim, B. H., Naowaboot, J., Lee, M. Y., Hyun, M. R., Cho, E. J. et. al. (2011). Effects of ferulic acid on diabetic nephropathy in a rat model of type 2 diabetes. Experimental and Molecular Medicine, 43 (12), 676-683. doi: http://doi.org/10.3858/ emm.2011.43.12.078

39. Hsu, C.-L., Yen, G.-C. (2008). Phenolic compounds: Evidence for inhibitory effects against obesity and their underlying molecular signaling mechanisms. Molecular Nutrition \& Food Research, 52 (1), 53-61. doi: http://doi.org/10.1002/mnfr.200700393

Received date 21.12.2021

Accepted date 26.01.2022

Published date 28.02.2022

Alla Kovaleva, Doctor of Pharmaceutical Sciences, Professor, Department of Pharmacognosy, National University of Pharmacy, Pushkinska str., 53, Kharkiv, Ukraine, 61002

Ain Raal, PhD, Professor of Pharmacognosy, Faculty of Pharmacy, Institute of Pharmacy, University of Tartu, Nooruse str., 1, Tartu, Estonia, 50411

Tetiana Ilina, Doctor of Pharmaceutical Sciences, Professor, Department of Pharmacognosy, National University of Pharmacy, Pushkinska str., 53, Kharkiv, Ukraine, 61002

Alina Osmachko, PhD, Assistant, Department of Pharmacognosy, National University of Pharmacy, Pushkinska str., 53, Kharkiv, Ukraine, 61002

Olga Goryacha, PhD, Assistant, Department of Pharmacognosy, National University of Pharmacy, Pushkinska str., 53, Kharkiv, Ukraine, 61002

Ludmila Omelyanchik, Doctor of Pharmaceutical Sciences, Professor, Dean, Zaporizhzhia National University, Zhukovsky str., 66, Zaporizhia, Ukraine, 69600

Oleh Koshovyi, Doctor of Pharmaceutical Sciences, Professor, Head of Department, Department of Pharmacognosy, National University of Pharmacy

Pushkinska str., 53, Kharkiv, Ukraine, 61002

*Corresponding author: Oleh Koshovyi,e-mail: oleh.koshovyi@gmail.com 